\title{
The efficiency of rhizobia use in the soybean cultivation on chernozem of the Western Ciscaucasia
}

\author{
Vyacheslav Lucomets*, Vladimir Tilba, Nikolay Tishkov, Vasily Makhonin, and Margarita \\ Shkarupa
}

V.S. Pustovoit All-Russian Research Institute of Oil Crops, 17 Filatova street, Krasnodar, 350038, Russian Federation

\begin{abstract}
In the period of 2008-2014, we carried out the field experiments to evaluate the efficiency of soybean inoculation with Russian and foreign preparations of nodule bacteria on various subtypes of chernozem of the Western Ciscaucasia. All studied inoculants ensured an increase of soybean yield: on ordinary chernozem - on average, by $18.8 \%(0.34 \mathrm{t} / \mathrm{ha})$, on leached and typical chernozems - by $14.9 \%(0.30 \mathrm{t} / \mathrm{ha})$, on meadow chernozem of rice fields - by $59.1 \%(1.04 \mathrm{t} / \mathrm{ha})$. The protein content from inoculation increased by $1.7-1.9 \%$, in rice crop rotations - by $4.0-4.9 \%$. There was no significant difference in efficiency between Russian and foreign inoculants. In 2018-2019, in a field experiment on leached chernozem we established the varietal specificity by reaction to inoculation with various strains of rhizobia in new soybean varieties Bars and Irbis, confirming the expediency of selecting complementary pairs in the system soybean variety - rhizobia strain.
\end{abstract}

\section{Introduction}

The modern agricultural production is faced with the task of a steady and considerable increase in the productivity of agricultural land. At the same time, the intensification of the plant growing industry and the increase in chemical loads on the soil lead to a worsening of the environmental conditions in cultivated land. The main negative consequence is a decrease in fertility of soil due to the increased human impact on the intensity and direction of the biological and biochemical processes taking place in it. All this dictates the need to refocus agriculture from an intensive chemical path to a safer biological one, considering the achievements of modern science [1-4].

Fertilizer application is the main way to regulate the supply of nutrients to plants. The most important of fertilizers are nitrogen ones, since nitrogen, being the main biological element, is absorbed in large quantities and is removed with the crop yield. However, the application of these particular fertilizers is associated with the biggest environmental risks due to the high mobility of compounds in the soil that can pollute the environment and accumulate in products in the form of nitrites, nitrates, etc., harmful to humans and animals.

\footnotetext{
*Corresponding author: soyagro15@yandex.ru
} 
The biological fixation from the atmospheric air by specialized microorganisms is the main way of the natural intake of nitrogen by the soil. According to some estimates, about $90 \%$ of the total number of molecular nitrogen enters the soil due to the biological fixation from the atmospheric air, and the share of applied nitrogen fertilizers is only about $10 \%$ [5]. Biologically fixed nitrogen is environmentally safe, it is not liable to the processes of removal and weathering and does not lead to accumulation of harmful compounds in products.

The nitrogen-fixing soil microorganisms are divided into free-living and symbiotic (nodule bacteria or rhizobia). In terms of the amount of fixed nitrogen, symbiotic nitrogen fixation is higher than non-symbiotic one by ten folds. Symbiotic interrelations with nodule bacteria are inherent only in legume crops; therefore, they are considered as improving soil fertility in crop rotations $[6,7]$. The presence of specific nodule bacteria inherent in each legume species is necessary for the development of a symbiotic apparatus on the roots of plants. Therefore, inoculation is required in case of moving legumes to places where they have not been cultivated previously.

The development of soybean farming in the North Caucasus region contributed to the spreading of soybean-specific nodule bacteria (Bradyrhizobium japonicum) in soil due to the seed inoculation with preparations based on domestic strains $[8,9]$. At the same time, some of the introduced bacterial forms were included in the soil-microbial cenosis, developing in a course of decades a stable community of soybean nodule bacteria with specific characteristics, which can be described as indigenous for these soils $[9,10]$. Domestic strains of rhizobia were used in production until 2007, and since 2008, foreign preparations began to spread - Brazilian, Argentinian, North American, etc.

The aim of this research was to evaluate the efficiency of soybean inoculation with various strains of rhizobia in terms of the impact on the size and quality of the yield on various subtypes of chernozem of the Western Ciscaucasia.

\section{Materials and methods}

We carried out the research in agricultural enterprises of various climatic zones of the Krasnodar region: Northern (in the Leningradsky, Kanevskoy and Kushchevsky districts); Central (in the Ust-Labinsky and Dinskoy districts and at the experimental field of V.S. Pustovoit All-Russian Research Institute of Oil Crops in Krasnodar); Western (at the rice farms of the Krasnoarmeysky, Slavyansky and Abinsky districts).

We carried out the experiments mechanically using the sowing equipment available at the farms. We cultivated soybean in a wide-row sowing according to the existing recommendations [11]. We inoculated the seeds with the studied preparations following the guidelines of their producers.

We carried out the experiment, observations, recordings, and analyses in accordance with the existing methodological requirements $[12,13]$. The size of plots was $112-168 \mathrm{~m}^{2}$, the number of replications was 4 . We counted the harvest using the Wintersteiger plot combine or by sheaf method. We carried out the biochemical analyses of seeds to determine the quality of harvest in the laboratory of biochemistry of V.S. Pustovoit All-Russian Institute of Oil Crops.

In the experiment, we used the new early-ripening varieties of soybean with high yield potential (Bars, Irbis, a variety with high protein content compared to the already released variety Slavia) to study the specificity of the varietal response to inoculation with various strains (2018-2019). 


\section{Results and discussion}

In our research we established a positive effect of soybean inoculation with the studied preparations on the productivity and protein content in seeds. On ordinary, leached, and typical chernozems of the Western Ciscaucasia in the steppe regions of the Northern and Central zones of the Krasnodar region the average yield increases from inoculation were 18.8 and $14.9 \%$ (0.34 and $0.30 \mathrm{t} / \mathrm{ha})$, respectively (Table 1$)$.

Table 1. The productivity and protein content in soybean seeds depending on inoculation of various origin in the soil and climatic zones of the Krasnodar region (average by 21 experiment, 2008-2014)

\begin{tabular}{|c|c|c|c|c|c|c|c|c|}
\hline \multirow{3}{*}{$\begin{array}{l}\text { Country of } \\
\text { origin of } \\
\text { inoculant, } \\
\text { preparative } \\
\text { form }\end{array}$} & \multicolumn{8}{|c|}{ The zone of the Krasnodar region, soil subtype } \\
\hline & \multicolumn{2}{|c|}{$\begin{array}{l}\text { Northern, } \\
\text { ordinary } \\
\text { chernozem }\end{array}$} & \multicolumn{2}{|c|}{$\begin{array}{c}\text { Central, } \\
\text { leached and } \\
\text { typical } \\
\text { chernozems }\end{array}$} & \multicolumn{2}{|c|}{$\begin{array}{c}\text { Western, } \\
\text { meadow } \\
\text { chernozem of } \\
\text { rice fields }\end{array}$} & \multicolumn{2}{|c|}{$\begin{array}{l}\text { average by the } \\
\text { zones of the } \\
\text { Krasnodar } \\
\text { region }\end{array}$} \\
\hline & $\begin{array}{c}\text { produc } \\
\text { tivity, } \\
\text { t/ha }\end{array}$ & $\begin{array}{c}\text { protein } \\
\text { conten } \\
t, \% \\
\end{array}$ & $\begin{array}{c}\text { produc } \\
\text { tivity, } \\
\text { t/ha }\end{array}$ & $\begin{array}{c}\text { protein } \\
\text { conten } \\
t, \% \\
\end{array}$ & $\begin{array}{c}\text { produc } \\
\text { tivity, } \\
\text { t/ha }\end{array}$ & $\begin{array}{c}\text { protein } \\
\text { conten } \\
t, \% \\
\end{array}$ & $\begin{array}{c}\text { produc } \\
\text { tivity, } \\
\text { t/ha }\end{array}$ & $\begin{array}{c}\text { protein } \\
\text { conten } \\
t, \% \\
\end{array}$ \\
\hline $\begin{array}{l}\text { Control, } \\
\text { without } \\
\text { treatment }\end{array}$ & 1.81 & 36.9 & 2.02 & 37.3 & 1.76 & 33.0 & 1.86 & 35.7 \\
\hline $\begin{array}{l}\text { Russia, } \\
\text { peat }\end{array}$ & 2.02 & 38.8 & 2.17 & 39.1 & 3.21 & 37.0 & 2.47 & 38.3 \\
\hline $\begin{array}{l}\text { Russia, } \\
\text { liquid }\end{array}$ & 2.12 & 38.9 & 2.38 & 39.1 & 2.03 & 37.0 & 2.18 & 38.3 \\
\hline $\begin{array}{l}\text { Brasilia, } \\
\text { peat }\end{array}$ & 2.29 & 38.6 & 2.37 & 39.2 & 3.25 & 37.9 & 2.64 & 38.6 \\
\hline $\begin{array}{l}\text { Argentine, } \\
\text { liquid }\end{array}$ & 2.08 & 38.9 & 2.32 & 38.8 & 3.00 & 37.8 & 2.47 & 38.5 \\
\hline $\begin{array}{l}\text { USA, } \\
\text { liquid }\end{array}$ & 2.23 & 38.7 & 2.38 & 39.0 & 2.49 & 37.9 & 2.37 & 38.5 \\
\hline $\begin{array}{l}\text { Average by } \\
\text { inoculants }\end{array}$ & 2.15 & 38.8 & 2.32 & 39.0 & 2.80 & 37.5 & 2.42 & 38.4 \\
\hline
\end{tabular}

As a rule, the nodules did not develop on the root of plants in the control on ordinary chernozem of the Northern zone of the region, which indicates the absence of indigenous populations of rhizobia in most fields of this zone. In the Central zone, in most cases, we observed the development of symbiotic apparatus in the control, but the obtained yield increases in variants with inoculation indicate that the indigenous populations of rhizobia are inferior to cultural strains in the effectiveness of symbiosis.

We received the largest increases in yield from inoculation on the soils of rice fields of the Western zone of the region, poor in available forms of mineral nitrogen. Here, the soil almost always lacked indigenous strains, apparently due to the death of rhizobia in the rice links of crop rotations, when the paddy fields are kept in a state flooded with water for a long time. The soybean productivity in paddy fields increased by an average of 1.5 times due to inoculation, and in some years the yield increased by more than $2.0-2.5$ times, which is explained by an acute deficiency of available nitrogen in the soil and favorable moisture conditions for the symbiotrophic process.

By inoculants, the average increase of soybean productivity from inoculation was $30.1 \%$ $(0.56 \mathrm{t} / \mathrm{ha})$.

Comparing domestic and foreign inoculants, we can state that they were similar in their impact on the soybean productivity. The Brazilian peat inoculant, which provided an average 
of $41.9 \%(0.78 \mathrm{t} / \mathrm{ha})$ increase in soybean yield in all experiments, was somewhat distinguished for its stability.

An improvement in nitrogen nutrition of plants during inoculation, along with an increase in productivity, also contributed to an increase in the protein content in soybean seeds, on average for all variants by 2.7 absolute percent, and on rice field soils - by $4.5 \%$.

At the same time, we should admit that sometimes the effect of inoculation is not significant. This can be explained not only by the activity of the indigenous rhizobia present in the soil, but also by the specificity of the new varieties and their interrelations with the rhizobia strains. In this regard, the problem of selecting determinant partners of symbiosis soybean variety - rhizobia strain becomes important.

In 2018-2019, we studied the reaction of the new soybean varieties to inoculation with rhizobia strains from the collection of indigineous microorganisms available at V.S. Pustovoit All-Russian Resesarch Institute of Oil Crops - strains 5/1 and 7p. We used the Argentinian inoculant approved for production use as a standard. At the beginning of the growth season, we observed a more intensive nodule development and an increase in the total biomass of plants of the varieties with inoculation, but the new varieties Bars and Irbis showed the reaction to inoculation close to neurtal in terms of the outcome indicator - seed yield. In the Slavia variety, in all inoculation variants, the yield increased by $8.7-13.0 \%$, and the highest yield was from the strain 5/1 (Table 2). There was no significant effect of inoculation on the protein content in seeds of all varieties.

Table 2. The productivity and protein content in seeds of new soybean varieties in case of inoculation with indigenous strains of rhizobia on leached chernozem (V.S. Pustovoit of All-Russian Research Institute of Oil Crops, Krasnodar, 2018-2019)

\begin{tabular}{|c|c|c|c|c|c|}
\hline \multirow[b]{2}{*}{ Variety } & \multirow[b]{2}{*}{ Strain of rhizobia } & \multicolumn{2}{|c|}{ Seed productivity } & \multicolumn{2}{|c|}{ Protein content } \\
\hline & & $\mathrm{t} / \mathrm{ha}$ & $\begin{array}{l}\% \text { to } \\
\text { control }\end{array}$ & $\%$ & $\begin{array}{c}+/ \text { - to control, } \\
\text { abs. } \%\end{array}$ \\
\hline \multirow{5}{*}{ Slavia } & $\begin{array}{c}\text { Control } \\
\text { (without } \\
\text { inoculation) }\end{array}$ & 2.07 & 100.0 & 39.7 & - \\
\hline & Standard & 2.31 & 111.6 & 39.7 & 0.0 \\
\hline & Strain 5/1 & 2.34 & 113.0 & 40.0 & +0.3 \\
\hline & Strain $7 p$ & 2.25 & 108.7 & 39.9 & +0.2 \\
\hline & $\begin{array}{c}\text { Average by } \\
\text { inoculants }\end{array}$ & 2.30 & 111.1 & 39.9 & +0.2 \\
\hline \multirow{5}{*}{ Bars } & $\begin{array}{c}\text { Control } \\
\text { (without } \\
\text { inoculation) }\end{array}$ & 2.36 & 100.0 & 40.2 & - \\
\hline & Standard & 2.31 & 97.9 & 40.4 & +0.2 \\
\hline & Strain $5 / 1$ & 2.41 & 102.1 & 40.2 & 0.0 \\
\hline & Strain $7 p$ & 2.26 & 95.8 & 39.6 & -0.6 \\
\hline & $\begin{array}{l}\text { Average by } \\
\text { inoculants }\end{array}$ & 2.33 & 98.7 & 40.1 & -0.1 \\
\hline \multirow{5}{*}{ Irbis } & $\begin{array}{c}\text { Control } \\
\text { (without } \\
\text { inoculation) }\end{array}$ & 2.56 & 100.0 & 42.9 & - \\
\hline & Standard & 2.66 & 103.9 & 43.1 & +0.2 \\
\hline & Strain $5 / 1$ & 2.61 & 102.0 & 42.3 & -0.6 \\
\hline & Strain $7 p$ & 2.60 & 101.6 & 43.2 & +0.3 \\
\hline & $\begin{array}{c}\text { Average by } \\
\text { inoculants }\end{array}$ & 2.62 & 102.3 & 42.9 & 0.0 \\
\hline
\end{tabular}


According to the yield data, we can observe a certain variety-strain relation. Preliminary, we identified complementary pairs of symbiotic partners: the Slavia variety with the strains $5 / 1$ and $7 \mathrm{p}$; the Bars variety with the strain $5 / 1$ and the Irbis variety with the strains $5 / 1$ and standard. The obtained results confirm the advisability of further research on the study of the peculiarities of variety-strain relations with rhizobia in soybean for the selection of the most effective partners of symbiosis in relation to specific cultivation conditions.

\section{Conclusions}

The results obtained on different subtypes of chernozems of the Western Ciscaucasia indicate a positive effect on the yield of soybeans and the accumulation of protein in seeds by inoculation of seeds with cultivated strains of rhizobia, providing an increase in yield by 14.9$18.8 \%(0.30-0.34 \mathrm{t} / \mathrm{ha})$ and an increase in the protein content by $1.7-1.9 \%$ in the steppe zone of the region, and the increase of yield more than 1.5 times and the protein content by $4.0-$ $4.9 \%$ in the paddy fields of rice crops rotations.

The seed inoculation should be considered as an integral part of the agricultural technology of soybean cultivation, even if the soil contains indigenous rhizobia capable of developing a symbiotic apparatus on plant roots.

Comparing modern domestic and foreign inoculants, we can state that they are similar in their impact on soybean productivity and the quality of the yield.

Considering a certain varietal specificity of soybean in response to inoculation by various strains of rhizobia, in case of new varieties, it is advisable to carry out research to select the most effective partners of symbiosis (strains of rhizobia).

\section{Acknowledgements}

The authors express their gratitude to Oleg Shirinyan, the president of the company "SOKO" and to Albert Shchegolkov, $\mathrm{PhD}$ in agriculture, for technical assistance in carrying out the research in 2008-2014.

\section{References}

1. A.A. Zhuchenko, Annals of the Russian Academy of Agricultural Sciences, 1, 3 (2006)

2. V.A. Zakharenko, Plant protection and quarantine, 5, 13 (2009)

3. V.A. Pavlyushin, Plant protection and quarantine, 2, 11 (2010)

4. V.D. Nadykta, Plant protection and quarantine, 4, 19 (2007)

5. A.B. Dyakov, Supraorganismal biological systems and principles of their studying (2019)

6. M.L. Rumyantseva, Agricultural biology, 5 (54), 847 (2019)

7. V.A. Tilba, Oil Crops, Sci. and tech. bull. of VNIIMK, 4 (168), 61 (2016)

8. V.F. Baranov, A.V. Kochegura, V.M. Lukomets, Soybean in the Kuban (2009)

9. M.V. Yakimenko, S.A. Begun, Annals of the Far-Eastern department of the RAS, 2, 45 (2016)

10. L.A. Dega, E.S. Butovets, L.M. Lukyanchuk, Plant protection and quarantine 11, 41 (2018) 
11. V.M. Lukomets, N.I. Bochkaryov, V.I. Khatnyansky [et al.]. Adaptive technologies of oil crops production in the southern region (2010)

12. V.M. Lukomets (Ed.), A methodology of conducting of field agricultural and technological trials with oil crops (2010)

13. B.A. Dospekhov, Methods of field trial with bases of statistic treatment of research results (2014) 